\title{
Multiple extraneural metastasis of glioblastoma multiforme
}

\section{Metástasis extraneurales múltiples de glioblastoma multiforme}

\author{
J. Undabeitia ${ }^{1}$, M. Castle ${ }^{1}$, M. Arrazola ${ }^{1,2}$, C. Pendleton ${ }^{3}$, I. Ruiz ${ }^{4}$, E. Úrculo ${ }^{1,2}$
}

\begin{abstract}
Introduction. Glioblastoma multiforme is the most frequent primary tumor in the brain. Despite improvements in its surgical, chemotherapy and radiotherapy treatment, prognosis remains poor. Extracranial metastases of glioblastoma are a rare complication in this disease. Its appearance has been described in lung, liver, bone or lymph nodes.
\end{abstract}

Case report. We describe the case of a 20 year-old patient who complained of a subacute-onset headache. In the MRI an enhancing right temporal lesion was detected suggesting a high grade glioma as first diagnosis. Surgery was performed, obtaining a gross total resection of the lesion. Our patient underwent adjuvant radiotherapy and chemotherapy treatment, according to our hospital's protocol. Five months after initial surgery our patient complained of chest pain and a hacking cough. A thoracicabdominal-pelvic CT scan was obtained, which showed bilateral lung infiltrates with pleural effusion, a pancreatic nodule and several vertebral lytic lesions. The lung lesions were biopsied. The pathologic diagnosis was metastatic glioblastoma multiforme. The patient died eight months after initial diagnosis

Conclusion. Extracranial metastases of glioblastoma remain a rare event although its incidence is increasing, probably due to the improvement in survival among these patients and better imaging techniques. The mechanisms for extracranial dissemination of glioblastoma are not entirely known, as several theories exist in this regard. Physicians must be aware of this complication and keep it in mind as a differential diagnosis to improve the quality of life of our patients.

\section{RESUMEN}

Fundamento. Los glioblastomas multiformes son los tumores cerebrales primarios más frecuentes. A pesar de los avances en su tratamiento quirúrgico, quimioterápico y radioterápico su pronóstico sigue siendo pobre. Las metástasis extracraneales de glioblastoma multiforme suponen una rara complicación dentro del curso de la enfermedad y ha sido descrita su aparición en distintas localizaciones como pulmón, hígado, hueso o ganglios linfáticos.

Caso clínico. Presentamos el caso de una paciente de 20 años que consultó por un cuadro de evolución subaguda Se obtuvo una RMN cerebral que demostró la presencia de una lesión temporal derecha, que sugería un glioma de alto grado como primera posibilidad diagnóstica. Se intervino a la paciente, realizando una resección macroscópicamente completa de la lesión. Se administró tratamiento radioterápico y quimioterápico adyuvante, de acuerdo con el protocolo de nuestro centro. Cinco meses después de la cirugía la paciente consultó por dolor torácio y tos seca. Se realizó un TAC toraco-abdomino-pélvico, que mostró la presencia de infiltrados pulmonares bilaterales con derrame pleural asociado, un nódulo pancreático y varias lesiones vertebrales líticas. Las lesiones pulmonares fueron biopsiadas. El diagnóstico anatomopatológico fue de metástasis de glioblastoma multiforme. La paciente falleció ocho meses después del diagnóstico inicial

Conclusiones. Las metástasis extracraneales de glioblastoma multiforme son un suceso poco frecuente, aunque su incidencia está aumentando en posible relación con el aumento de la supervivencia de nuestros pacientes. La aparición de esta complicación se asocia a un estado terminal de la enfermedad. A pesar de su baja frecuencia se debe mantener un alto nivel de sospecha en su diagnóstico para poder mejorar la calidad de vida de estos pacientes.
1. Neurosurgery Department. Donostia University Hospital. San Sebastián, Spain

2. Surgery Department. University of the Basque Country Medical School. San Sebastián, Spain

3. Neurosurgery Department. Thomas Jefferson University Hospitals. Philadelphia (PA), USA

4. Pathology Department. Donostia University Hospital. San Sebastián, Spain

Recepción: 9 de noviembre de 2014

Aceptación provisional: 7 de enero de 2015

Aceptación definitiva: 7 de enero de 2015

\section{Corresponding author}

J. Undabeitia

Servicio de Neurocirugia

Hospital Universitario Donostia

$\mathrm{C} /$ Dr. Beguiristain 117

20080 San Sebastián

Gipuzkoa

Email: joseundabeitia@hotmail.com

Authors declare no conflict on interests

Funding: n/a 


\section{INTRODUCTION}

Glioblastoma multiforme (GBM) remains the most frequent primary tumor of the central nervous system (CNS) in adults, and accounts for $17.1 \%$ of all CNS tumors ${ }^{1}$. Despite advances in operative and adjuvant therapies, the prognosis remains dismal, with a survival rate of less than $12 \%$ within two years after initial diagnosis ${ }^{1}$.

While GBM are notable for local invasion and recurrence, extracranial metastases are a rare event. It is hypothesized that this may be due to the protective blood brain barrier and the absence of lymphatic vessels. The incidence of GBM extracranial metastases has increased over time, from $0.44 \%$ in 1969 , to $2 \%$ at present ${ }^{2}$. Distant metastases are often diagnosed concurrent with intracranial tumor progression, and may follow an intracranial operation, such as craniotomy, sterotactic biopsy, or shunt placement. Dissemination of GBM tumor cells may be enabled by operative manipulations, which increase the disruption of the blood brain barrier, and allow tumor cells to enter systemic circulation and track along the operative corridor. However, there are case reports of GBM metastases occurring in the absence of operative intervention ${ }^{3}$.

GBM metastatic lesions are most commonly found in the lungs, pleura, lymph nodes, liver, and bone ${ }^{4}$.

\section{CASE REPORT}

The patient, a 20 year-old female with no significant previous medical or surgical history, presented with subacute onset frontal headache and occasional vomiting. Neurological examination was entirely normal. An MRI of the brain was obtained, which showed an enhancing right temporal lesion (Figs. 1a,1b,1c).
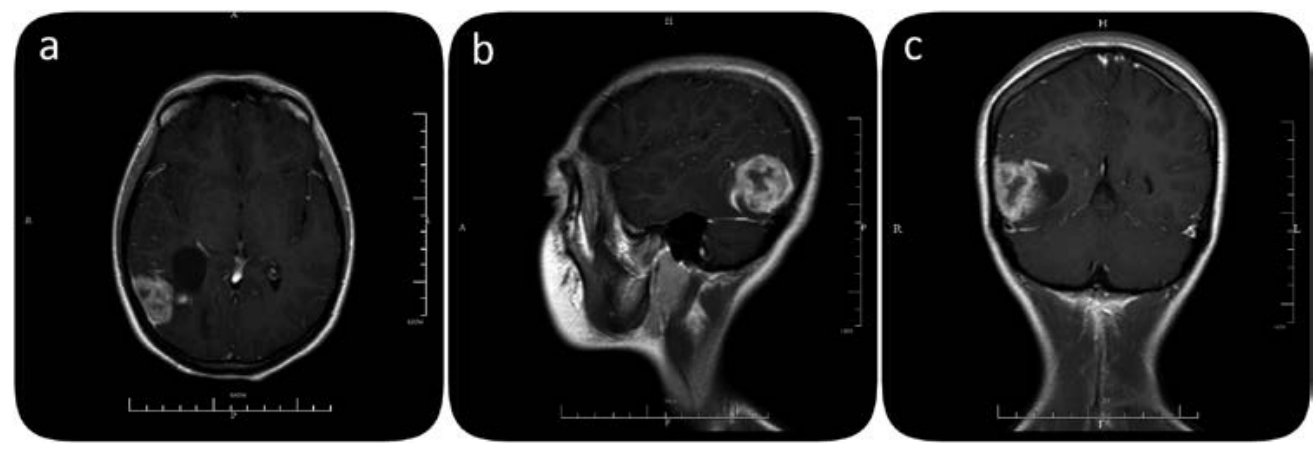

Figure 1. Axial (a), sagittal (b) and coronal (c) contrast enhanced T1 brain MRI.

Ten days after diagnosis, a craniotomy was performed. After the bone flap was removed a tumor-infiltrated dura mater was exposed. During the procedure an incidental opening of the transverse sinus occurred, which was successfully repaired. A gross total resection was achieved. Post-operatively, no neurological deficits were detected. 48 hours after surgery a new brain MRI was obtained, which demonstrated total resection of the lesion. The final pathology report was GBM (WHO grade IV). The patient was discharged without any complications on the eighth post-operative day. She received adjuvant radiotherapy and chemotherapy treatment
(60Gy, Temozolomide $75 \mathrm{mg} / \mathrm{m} 2$ per day) over a three-month period. No side effects were observed during this treatment.

Approximately one month after completing her radiotherapy and five months after surgery, the patient complained of chest pain and dry, hacking cough. The chest X-ray showed bilateral lung infiltrates (Fig. 2a). An infectious disease in an inmunocompromised patient was suspected and antibiotic treatment was initiated, with no clinical improvement. At this point a thoracic abdominal pelvic CT scan was performed, which showed the previously described infiltrates with pleural effusion, a pancreatic nodule and several 


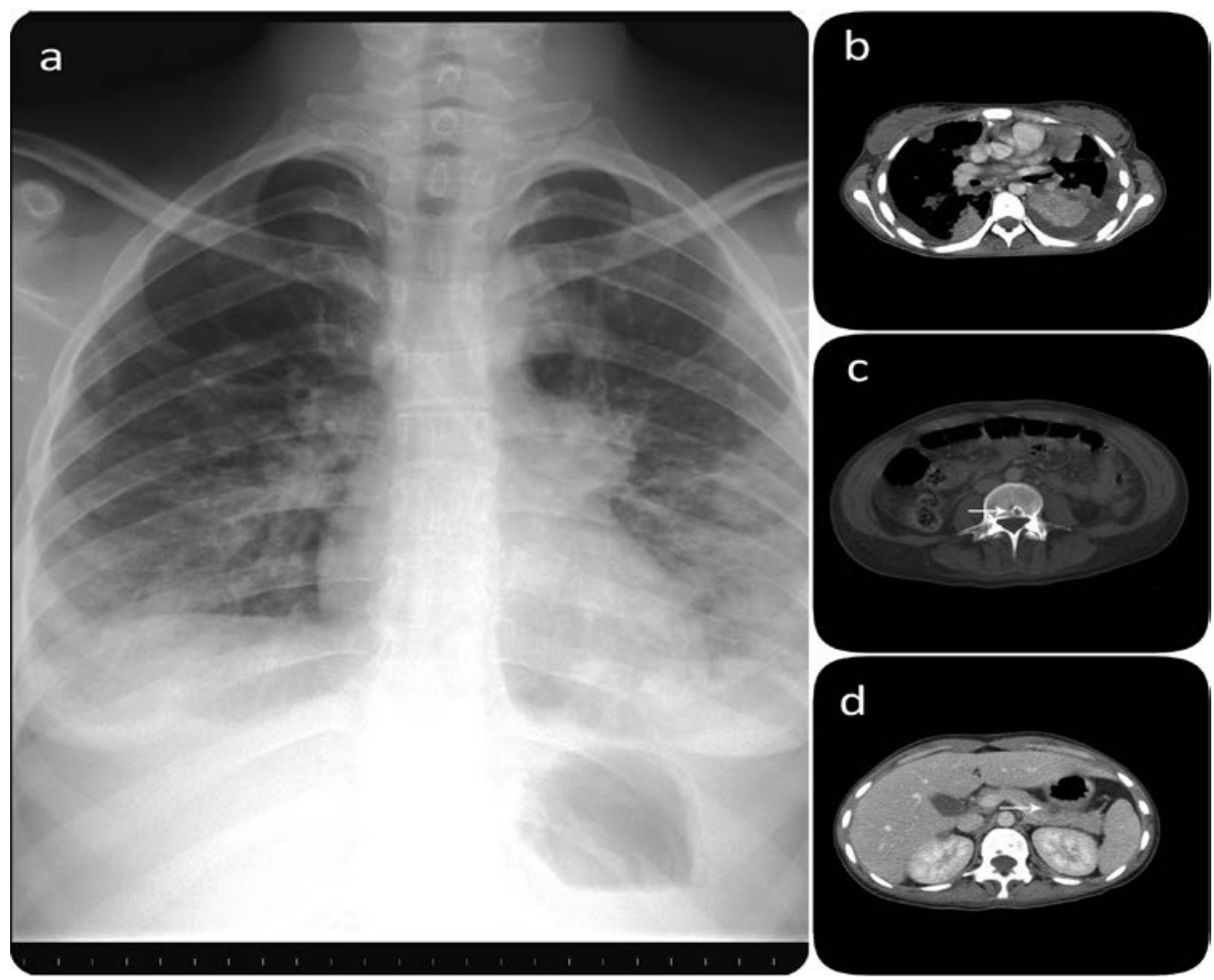

Figure 2a: Posterior-anterior torax X-ray showing bilateral diffuse lung infiltrates. 2b, 2c and 2d Thoracic abdominal pelvic ct scan showing pleural effusion (b), a pancreatic nodule (c, arrow) and a vertebral lytic lesion (d, arrow).

vertebral lytic lesions (Figs. 2b,2c,2d). The pulmonary infiltrates were biopsied. The pathology report informed of a metastatic glioblastoma. Second line treatment with irinotecan (CPT-11) and bevacizumab was started. Our patient progressively deteriorated and, despite optimal medical management, she died with an overall survival of eight months from the time of diagnosis.

\section{DISCUSSION}

Strict criteria for diagnosing extraneural metastases from primary CNS tumors were established by Weiss et al in 1955, including a clinical history of primary CNS tumor, complete post-mortem examination to rule out undiagnosed primary periphe- ral tumors, and histological correlation between the primary CNS tumor and the presumed extraneural metastases ${ }^{5}$.

Metastases of GBM have been documented in the literature throughout the twentieth century. Bailey and Cushing described leptomeningeal metastases of intracranial glioma in $1926^{6}$, and Davis provided the first description of extraneural GBM metastasis in 1928, using the term spongioblastoma $^{7}$ Although high grade glioma metastasis, or spread, throughout the central nervous system, along physiologic or artificial cerebrospinal fluid pathways, has been well documented ${ }^{8}$, extraneural metastasis remains a rare entity. A review of the literature from 1928 to 2006 demonstrates fewer than 130 reported cases of extraneural GBM 
metastases. The incidence of these lesions has increased in recent years; the literature review demonstrated only 21 cases reported from 1928 to 1967, and 107 cases reported from 1968 to 2006, a five fold increase ${ }^{2}$. Multiple explanations exist for this phenomenon, including increased interest among specialists in authoring case reports on this topic, and improved access to neurosurgical care, improved neuro-imaging, and advances in the multimodal treatment of gliomas. In particular, improvements in neuro-imaging techniques and therapeutic advances allow earlier diagnosis and longer patient survival, increasing the timeframe in which GBM cells may spread and form extracranial metastases ${ }^{4,9}$. Extraneural metastases are considered to be a sign of advanced disease and frequently occur between 8 to 24 months following the initial diagnosis ${ }^{10}$.

The rarity of extraneural metastases may be explained by the significant protective mechanisms isolating the CNS, including blood brain barrier and the protective dura mater, as well as by the absence of lymphatic vessels ${ }^{11,12}$. Tumor cells which bypass these protective barriers, may be prevented from establishing metastases by an extraneural mileu not conducive to GBM growth, as well as by the presence of a robust host immune response 12. In addition, it is hypothesized that the rarity of extraneural metastases may be due to the aggressive nature of GBM: patients may succumb to the primary tumor, or the increased intracranial pressure and subsequent herniation that accompanies significant tumor progression, before tumor cells have the opportunity to metastasize ${ }^{12}$.

Reports of extraneural GBM metastases show a strong correlation between these lesions and preceding intracranial operations ${ }^{11,12}$, although extraneural metastases in the absence of operative intervention have also been described ${ }^{3}$. While intracranial operations are not absolutely necessary in the development of extraneural GBM metastases, such operations provide opportunities for tumor cells to come into contact with extraneural blood vessels and lymphatic vessels, thereby increasing the risk of systemic spread and extraneural tumor seeding ${ }^{13}$. Neurosurgeons should try to minimize these risks by changing surgical gloves and instruments after completing the intradural portion of an operation, copiously irrigating the resectioncavity prior to closure and performing a watertight closure of the dura when possible ${ }^{14}$.

Regarding the genetic and molecular features, Park et al. suggested that the metastatic potential of the GBM might be related to P53 gene mutatations and differential clone selection ${ }^{15}$. Several studies using de cDNA microarray technique have showed common findings, such as overexpression of the insulin growth factor and a decrease of DNA-PK genetic expression, which is involved in DNA repair mechanisms. The former is probably related to tumor progression, while the later plays a role in malignant transformation of glioma ${ }^{16}$.

As treatment for GBM improves patient survival, incidence of extraneural metastases may continue to increase. Physicians should continue keeping in mind extraneural metastases in their differential diagnosis for patients with a known GBM and extraneural symptoms that are not otherwise explained. A detailed investigation of systemic complaints in patients with a known GBM may prevent extraneural metastases from being overlooked ${ }^{17,18}$. It has previously been recommended that patients who have survived a significant period of time following their initial diagnosis of GBM should undergo screening for extraneural metastases if they develop new intracranial lesions, or their primary tumor recurs following treatment. Although these metastases carry a poor prognosis, the diagnosis and treatment of such lesions offers palliative benefit, and may improve patient quality of life $\mathrm{e}^{17,18}$.

Extracranial metastases of glioblastoma remains a rare event. We must expect an increasing incidence, probably due to improvement in survival among these patients and better imaging techniques. The mechanisms for extracranial dissemination of glioblastoma are not entirely known, as several theories exist in this regard. Physicians must be aware of this complication and keep it in mind in their differential diagnosis to improve the quality of life of our patients. 


\section{REFERENCES}

1. Stupp R, Mason WP, van den Bent MJ, Weller M, FISHER B, TAPHOORN MJ et al. Radiotherapy plus concomitant and adjuvant temozolomide for glioblastoma. N Engl J Med 2005; 352: 987996.

2. Piccirilli M, Brunetto GM, Rocchi G, GiangaspeRo F, SALVATI M. Extra central nervous system metastases from cerebral glioblastoma multiforme in elderly patients. Clinico-pathological remarks on our series of seven cases and critical review of the literature. Tumori 2008; 94: 40-51.

3. Hulbann $\mathrm{S}$, Goodman PA. Glioblastoma multiforme with extraneural metastases in the absence of previous surgery. Cancer 1976; 37: 1577-1583.

4. Kraft M, Lang F, Braunschweig R, Janzer RC. Parotid gland metastasis from glioblastoma multiforme: a case report and review of the literature. Eur Arch Otorhinolaryngol 2008; 265: 709-711.

5. WeISS L. A metastasizing ependymoma of the cauda equina. Cancer 1955; 8: 161-171.

6. Cushing H, Balley P. Tumors of the glioma group. Philadelphia: JB Lippincott; 1926.

7. Davis L. Spongioblastoma Multiforme of the Brain. Ann Surg 1928; 87: 8-14.

8. Asencio-Cortes C, de Quintana-Schmidt C, ClavelLaria P, Catala Antunez I, Montes Graciano G, Molet Teixido J. Spinal cord metastasis from gliosarcoma. Case report and review of the literature. Neurocirugia 2014; 25: 132-135.

9. Beauchesne P, Soler C, Mosnier JF. Diffuse vertebral body metastasis from a glioblastoma multiforme: a technetium-99m Sestamibi single-photon emission computerized tomography study. J Neurosurg 2000; 93: 887-890.
10. Armstrong tS, Prabhu S, Aldape K, Hossan B, Kang S, Childress A et al. A case of soft tissue metastasis from glioblastoma and review of the literature. J Neurooncol 2011; 103: 167172

11. Figueroa P, Lupton JR, Remington T, Olding M, Jones RV, SEKHAR LN et al. Cutaneous metastasis from an intracranial glioblastoma multiforme. J Am Acad Dermatol 2002; 46: 297-300.

12. Ley A, Campillo D, Oliveras C. Extracranial metastasis of glioblastoma multiforme. J Neurosurg 1961; 18: 313-330.

13. Frank S, Kuhn SA, Brodhun M, Mueller U, RoMEIKE B, KOSMEHL $\mathrm{H}$ et al. Metastatic glioblastoma cells use common pathways via blood and lymphatic vessels. Neurol Neurochir Pol 2009; 43: 183-190.

14. Jain N, Mirakhur M, Flynn P, Choudhari KA. Cutaneous metastasis from glioblastoma. $\mathrm{Br} \mathrm{J}$ Neurosurg 2005; 19: 65-68.

15. Park CC, Hartmann C, Folkerth R, Loeffler JS, Wen PY, Fine HA et al. Systemic metastasis in glioblastoma may represent the emergence of neoplastic subclones. J Neuropathol Exp Neurol 2000; 59: 1044-1050.

16. Ueda S, Mineta T, Suzuyama K, Furuta M, ShiraisHI T, TABUCHI K. Biologic characterization of a secondary glioblastoma with extracranial progression and systemic metastasis. Neuro Oncol 2003; 5: 14-18.

17. Nigogosyan G, De La Pava S, Pickren JW. Brain tumor with extracranial metastases. Report of two cases. Arch Neurol 1962; 6: 300-306.

18. Mujic A, Hunn A, Taylor AB, Lowenthal RM. Extracranial metastases of a glioblastoma multiforme to the pleura, small bowel and pancreas. J Clin Neurosci 2006; 13: 677-681. 